\title{
Promoting Online Reading Habit Among Undergraduate Students by Reviewing and Summarizing E-Journal to Complete Academic Tasks
}

\author{
Elanneri Karani \\ University of Palangka Raya (UPR) \\ Palangka Raya, Indonesia
}

\begin{abstract}
Today, reading online activity is not only a trend but also an essential need among students at the university. Because online reading habit contributes significantly to the EFL learners successful in academic performance. This article reports what outcomes are resulted from reviewing and summarizing $E$ journal to complete academic tasks that promote online reading habit among undergraduate students at English Language Education Program of Teacher Training and Education Faculty, University of Palangka Raya. A questionnaire was used for data collection from 200 respondents, and descriptive statistics were used for data analysis. Findings showed that: most $(\mathbf{9 7 . 5 \% )}$ of the students reviewed E-journals as main references to write summaries, essays as final project-reports, thesis proposal, and research report; 2 ) all students $(\mathbf{1 0 0 \%})$ claimed that the written products they produced were in the form of summaries, essays as final project-reports, research proposal, and research report, 3) the E-journals they read and referred most were: TEFLIN Journal, RELC (Singapore), The Asian EFL Journal and The Journal of Asia TEFL, and 4) all students (100\%) stated that reviewed and summarized E-journal were very useful and meaningful to search ELT instruction and or research which are used to complete their academic tasks. So that the availability of accessible E-Library across universities all over Indonesia is urgent to provide in order promoting online reading habit and developing quantity and quality of research among faculty members.
\end{abstract}

Keywords-Online reading habit; reviewing; summarizing; $E$ journal; academic task.

\section{INTRODUCTION}

Nowadays, the internet plays a significant role in our daily life, and it has penetrated equally the field of education $[2] ;[10] ;[15]$. It has created an easy access to enter the digital world of the computer at ease of learning online. Students all over the world are using English when they are involved in activities such as reading online via the internet [4]. The fact that majority of internet users communicate online in English has made English learners realize the usefulness of learning the language to enable them to access to interesting online sources [9]. It is because English is not only the language of international communication but also the main language on the internet. So that students can easily obtain up-to-date information from all over the world by reading information online in English in form of PDF texts, for example.
Internet users grow rapidly among the students not only at junior high schools but also among students at university[7]; [10].In developing countries such as Indonesia, the use of the internet by students is so widespread that one feels outdated by not using it. They can access the internet easily via smartphone, and gadget to find thousands of various newspapers and journal on the internet today[13]; [11] because it provides multipurpose needs for internet users to customers [9]. Faculty member's needs are different than politician needs. The faculty members require, for example, E-book, E-journal, tutorial teaching videos, PDF English texts, and much more information concerning academic activities, such as international conferences and or workshops from all over the world.

People in university, are faculty members who have daily academic activities, such as lecturing, discussing, writing and reading many scientific papers, articles, books, research-basedarticles, and electronic journals (e-journal) . Nowadays, in the digital era, the faculty members can also access and download those academic products freely from the internet. Students at University can make use these electronics sources of knowledge to complete academic tasks anytime, and anywhere they need it via smartphone, a small computer, and many others electronic means. Readers who accustom to do this activity, know exactly that reading online involves eyes interaction, computer screen, text presented in hypertext, and comprehension of verbal and non-verbal information [5]; [12]. This phenomenon slowly but sure transforms readers' reading habit from reading the printed off texts into the online reading habit of the online reading texts. Therefore, the ability to read the academic text in English is considered one of the most important skills that university students of English as a second language and or English as a foreign language need to acquire. Reading as a habit not only can support the success of the learning process but also has a positive influence on academic performance [3]; [18]. These facts suggest that having good skills in reading English texts is demanding and establishing good reading habits in English is significant as well [13]; [14].

In contrast, traditional text forms which typically include a combination of two types of media, print and two dimensional - graphics, online texts integrate a range of symbols, audio, interactive tables, virtual reality environments and much more in English [6]; [19]; [20]. Readers read electronic texts introduce new supports as well as new challenges that can have an impact on an individual's ability to comprehend what she or 
he reads [16]; [17]. It is because reading electronic texts is different from printed texts as the strategies involved in processing the information online text are not the same, although some are applicable to both media, while others are more exclusive for online comprehension [10]; [21], [12]. Therefore, students in the digital era do not only have to adjust their reading behavior from traditional to digital texts, but they also need to practice necessary digital literacy skill to help them comprehend and cope with online texts well [6]; [21]; [1]. Today many more students involve learning online, are required to have good online reading skill. So that reading ejournal online among students who study English as ESL or EFL is important to develop in order that promoting online reading habit.

Many countries all over the world have the same challenge, that is how to develop reading habit among young people, particularly students. Many research on reading habit online conducted in many countries reported the following information. First, a research conducted in Ireland, to examine the reading habits relating to academic articles in PDF format, reported that only $29 \%$ of students use digital highlight or underlining functions and $12 \%$ add electronic comments to the articles itself. However, $70 \%$ the majority, take notes on paper when reading from a screen and $28 \%$ use a word processor to record notes [19]. This indicates students in Ireland have good reading habit online. Second, in other countries, for example, in Turkey students rarely read journal articles online they prefer to read online news, emails, weather reports and comic strips [5]. A research in Ghana, reports that students acknowledge the importance of reading habit and most of them (62\%) include in research sample claim they read only for the purpose to pass the examination. This confirms that reading habit online has an influence on academic performance [3]. A research conducted in Taiwan, reveals that the students have fairly- satisfactory English proficiency, however, they, in general, are not interested in after-class English reading[8]. A research conducted in Malaysia reports, students accustomed to going online to read. Unfortunately, they go online for entertainment purposes more often than they do for educational purposes [2]. These findings open our mind that in developing countries, every day many students go online, they do this activity for multi-purposes, some of them are reading for entertainment, however, still many more of them fight for good online readers, that is reading online for academic purposes.

In countries where students study English as a foreign language, such as undergraduate students at University of Palangka Raya, Indonesia, they are engaged a lot with both printed texts and online texts and references written in English to complete their academic tasks [6]. Consequently, reading a lot of online texts in English that is by reviewing and summarizing as many articles from e-journals to complete academic tasks is necessary to do. This activity also helps students to develop their online reading skill [15]; [8]. If students established these activities regularly, they could promote themselves to become active online texts - readers in English, but also could have a good online reading habit in the future.

The Much previous research focused on EFL students reading habit in Indonesian context could be generated into two main points. First is that the EFL students are the reluctant and lack of interest in reading, this occurs for some reasons and factors. For example, it is due to the limited background knowledge, inability to understand the context, and complicated organization of the text [13]; [15]. Second, research findings on EFL students who have a reading habit and what makes they establish a good reading habit. Findings reveal that the establishment of the EFL students reading habits in English is contributed by the individual, social, cultural and technological construct factors [13]; [14]. These facts revealed, many students at a university in Indonesia still need some attempts to improve their reading habit in English, and the transformation of old reading style that is reading printed English texts to reading online English texts is necessary to develop.

The Internet offers so many reading online English PDF texts which can make language learning in English is easier and more successfully managing. However, it is a dilemma for EFL students at University particularly those who are not skillful to read online English texts and have no sufficient experience as successful readers of English texts [13]; [14]. As a result, most them are still challenging to improve their English online reading habits. Seemingly, previous research findings are still not satisfying enough to answer what academic activities that able to promote online reading habit among EFL students, especially who are at undergraduate level. Therefore, the current research is intended to explore how reviewing and summarizing e-journals activities to complete academic tasks able to promote online reading habit among undergraduate students at the university. The general research question proposed in this case, is: What are the outcomes resulted from reviewing and summarizing E-journal activities to complete academic tasks that promote online reading habit among undergraduate students at English Language Education Program of Teacher Training and Education Faculty, University of Palangka Raya? Specifically, it separates into following questions:

- What is sort of academic tasks undergraduate students done by reviewing and summarizing E-journals to complete academic tasks that promote students' online reading habit?

- What are the forms of written products, undergraduate students result based on reviewing and referring to Ejournal to complete academic tasks that promote students' online reading habit?

- What are the E-journals of ELT and research the students read and refer most to complete academic tasks that promote students' online reading habit?

- What is the students' perception of reviewing and summarizing E-journal activities to complete academic tasks that promote students' online reading habit?

This article mainly discusses what outcomes are resulted from reviewing and summarizing E-journal to complete academic tasks as attempts to promote online reading habit among undergraduate students at English Language Education Program of Teacher Training and Education Faculty, University of Palangka Raya. The main objective of the present research is separated into specific points, are: 1) to identify the 
sorts of academic tasks are undergraduate students done by reviewing and summarizing E-journal to complete academic tasks that promote students' online reading habit; 2) the forms of written products they result based on reviewing and referring to E-journal to complete academic tasks that promote students' online reading habit, 3) E-journals of English language teaching - learning/research that the students read and refer most to complete academic tasks that promote students' online reading habit, and 4) students' perception of reviewing and summarizing E-journal activities to complete academic tasks that promote students' online reading habit.

\section{METHODS}

This research employed a questionnaire survey distributed to 200 undergraduate students of English Language Education Department of Teacher Training and Education Faculty, the University of Palangka Raya who have passed 'Scientific Writing" course. The students who joined this class read many ELT research-based articles from many e-journals. At the end of the semester they have blogs: blog A and blog B. Using these blogs students uploaded research-based articles based on the references they made by reviewing and summarizing ejournals so that students can read their classmates' articles as well. These activities are to lead students to read more ejournals. In addition, the questionnaire was developed by the researcher and validated by experts. The questionnaire consists of one closed-ended section- with yes-no choice answers and one opened-ended question asking for the respondents' perceptions of the ways they read by reviewing and summarizing E-journals. The collected data were analyzed by using descriptive statistics with percentage, displayed in tables and explained qualitatively. These are used to reveal if reviewing and summarizing e-journal activities to complete academic tasks able to promote online reading habit among undergraduate students at the university.

\section{RESUlTS AND CONCLUSIONS}

The results of the analysis are presented and discussed in this section to answer research questions. It deals with what the sorts of academic tasks are undergraduate students done by reviewing and summarizing E-journal to complete academic tasks that promote students online reading habit; what the forms of written products they result based on reviewing and referring to E-journal to complete academic tasks that promote students' online reading habit; what the E-journals of English language teaching - learning/research that the students read and refer most to complete academic tasks that promote students' online reading habit, and what students' perception of reviewing and summarizing E-journal activities to complete academic tasks that promote students' online reading habit.

\section{A. What sorts of academic tasks are undergraduate students done by reviewing and summarizing e-journal?}

Out of a total number of respondents (200), there $97.5 \%$ of them inform that review E-journals as main references to write summaries, essays as final project-reports, thesis proposal, and research report. The sorts of academic tasks done by the students based on the frequency of cases can be seen completely in Table I.
TABLE I. SORTS OF ACADEMIC TASKS ARE DONE BY THE STUDENTS BASED ON REVIEWING AND SUMMARIZING E-JOURNALS

\begin{tabular}{|l|c|c|}
\hline \multicolumn{3}{|c|}{ Sorts of Academic Tasks done by students } \\
\hline \multicolumn{1}{|c|}{ Tasks } & $\boldsymbol{F}$ & $\%$ \\
\hline $\begin{array}{l}\text { Write summaries and essay } \\
\text { as a final project }\end{array}$ & & \\
\hline Write essay as final project & & \\
\hline Write research proposal, & 5 & $2.5 \%$ \\
\hline Write research report & 195 & $97.5 \%$ \\
\hline $\begin{array}{l}\text { Write summaries, essay as final project, } \\
\text { research proposal and } \\
\text { research report }\end{array}$ & 200 & $100 \%$ \\
\hline \multicolumn{2}{|c|}{ Total } & \\
\hline
\end{tabular}

\section{B. The forms of written products the students result from} reviewing and summarizing E-journal to complete academic tasks

Based on the analysis to answer research question 3, the results show, all the written products the students result based on reviewing and summarizing e-journals are in the form of summaries, the essay as a final project, research proposal, and research report. It is shown in Table 2 below.

TABLE II. THE FORM OF WRITTEN PRODUCTS THE STUDENTS RESULT BASED ON REVIEWING SUMMARIZING E-JOURNALS

\begin{tabular}{|l|c|c|}
\hline \multicolumn{1}{|c|}{ Form of written products } & F & \% \\
\hline summaries and essay as a final project & & \\
\hline Essay as final project & & \\
\hline Research proposal, & & \\
\hline Research report & & \\
\hline $\begin{array}{l}\text { Summaries, essay as final project, } \\
\text { research proposal, and research report }\end{array}$ & 200 & $100 \%$ \\
\hline
\end{tabular}

\section{E-journals of English language teaching-learning/ research that the students read and referred most}

Findings show that, there four (4) journal the students read and refer most when they assign to complete academic tasks, namely: TEFLIN journal, RELC, The Asian EFL Journal, and The Journal of Asia TEFL. A complete data are shown in Table 3a below.

TABLE III. TABLE 3A. THE E-JOURNALS OF ENGLISH LANGUAGE TEACHING-LEARNING/THE STUDENTS READ AND REFERRED MOST

\begin{tabular}{|c|c|c|}
\hline E-journals in Indonesia & F & \% \\
\hline TEFLIN Journal & 92 & $46 \%$ \\
\hline RELC Journal & 57 & 28.5 \\
\hline The Asian EFL Journal & 18 & $9 \%$ \\
\hline The Journal of Asia TEFL & 17 & $8.5 \%$ \\
\hline Total & 184 & $92 \%$ \\
\hline
\end{tabular}

In addition, few (8\%) out of 200 respondents, that is 16 respondents claim, they ever read other e-journals, namely: Kata@ journal, International Journal of Applied Linguistics, International Journal of Language Education and Culture Review, International of English Language Teaching, KOTESOL journal, Thai TESOL Journal, TESOL Quarterly journal, Teacher Education Journal, PELTA journal, JALT, METLA journal. 
TABLE IV. THE E-JOURNALS OF ENGLISH LANGUAGE TEACHINGLEARNING/RESEARCH THAT THE STUDENTS READ AND REFER MOST

\begin{tabular}{|l|c|c|}
\hline \multicolumn{1}{|c|}{ E-Journals overseas } & F & $\%$ \\
\hline KATA@ journal & 2 & $1 \%$ \\
\hline $\begin{array}{l}\text { International Journal of Applied } \\
\text { Linguistics (IJAL) }\end{array}$ & 1 & $0.5 \%$ \\
\hline $\begin{array}{l}\text { International Journal of Language } \\
\text { Education } \\
\text { and Culture Review (IJLECR) }\end{array}$ & 1 & $0.5 \%$ \\
\hline $\begin{array}{l}\text { International of English Language } \\
\text { Teaching (IJELT) }\end{array}$ & 1 & $0.5 \%$ \\
\hline KOTESOL Journal & 1 & $0.5 \%$ \\
\hline Thai TESOL Journal & 1 & $0.5 \%$ \\
\hline TESOL Quarterly & 3 & $1.5 \%$ \\
\hline Teacher Education Journal & 2 & $1 \%$ \\
\hline PELTA Journal & 1 & 0.5 \\
\hline JALT Journal & 2 & $0.5 \%$ \\
\hline MELTA Journal & 16 & $8 \%$ \\
\hline \multicolumn{1}{|c|}{ Total } &
\end{tabular}

D. Perception of students reviewing and summarizing Ejournal Activities to complete academic tasks.

The students are asked to respond to the questionnaire after they practice reviewing and summarizing ELT articles from ejournals. The distributed questionnaire return completely. The analysis show all students $(100 \%)$ stated that reviewed and summarized ELT articles from E-journal were very useful and meaningful to complete academic tasks. They also claimed, they could search and access so many ELT research-based articles easily by using smartphones and others mobile means. They also confessed if they were happy to read ELT articles because they can do it anytime and anywhere. Now they realized, the activity of reading online is fun to do. The specific description can be seen in Table IV.

TABLE V. PERCEPTION OF STUDENTS REVIEWING AND SUMMARIZING EJOURNAL ACTIVITIES TO COMPLETE ACADEMIC TASKS.

\begin{tabular}{|c|c|c|c|}
\hline $\begin{array}{c}\text { Perception of The Students of Reviewing and } \\
\text { Summarizing } \\
\text { E-journal to Complete Academic Tasks }\end{array}$ & $\begin{array}{l}\text { A } \\
(\mathbf{f})\end{array}$ & $\begin{array}{l}\text { Da } \\
\text { (f) }\end{array}$ & $\%$ \\
\hline $\begin{array}{l}\text { I am happy to review and summarize ELT } \\
\text { articles from e-journals }\end{array}$ & 200 & - & $100 \%$ \\
\hline $\begin{array}{l}\text { Reviewing ELT articles from e-journal is } \\
\text { important to develop my online reading habit }\end{array}$ & 200 & - & $100 \%$ \\
\hline $\begin{array}{l}\text { I read more than two ELT articles from e- } \\
\text { journals weekly }\end{array}$ & 200 & - & $100 \%$ \\
\hline $\begin{array}{l}\text { I use the summary of articles from e-journals to } \\
\text { complete my academic assignment }\end{array}$ & 200 & - & $100 \%$ \\
\hline $\begin{array}{l}\text { I can search and download ELT articles from e- } \\
\text { journal by using smartphone, gadget, and tablet. }\end{array}$ & 200 & - & $100 \%$ \\
\hline $\begin{array}{l}\text { While reading ELT articles from e-journal I } \\
\text { write down some important notes }\end{array}$ & 200 & - & $100 \%$ \\
\hline $\begin{array}{l}\text { I review ELT articles from e-journal to } \\
\text { complete } \\
\text { Academic } \\
\text { assignment. }\end{array}$ & 200 & - & $100 \%$ \\
\hline $\begin{array}{l}\text { I summarize ELT articles from e-journal to } \\
\text { complete } \\
\text { my academic assignment. }\end{array}$ & 200 & - & $100 \%$ \\
\hline $\begin{array}{l}\text { I am happy to share my PDF texts-collection } \\
\text { to my classmates }\end{array}$ & 200 & - & $100 \%$ \\
\hline
\end{tabular}

\section{RESULTS AND DISCUSSIONS}

This article has shown that there are many outcomes the students resulted from reviewing and summarizing articles from e-journals to complete academic tasks. In detail it explains, first, finding proves that the summaries of ELT articles they reviewed, were very useful for them to complete academic tasks assigned by the lecturer/s. They made use the synopsis to write down: summaries, essays as final-report, research proposal, and research report. The finding was antithesis with the previous research finding that informs the EFL students are reluctant and lack of interest in reading, this happens due to the limited background knowledge, inability to understand the context, and complicated organization of the text [13]; [15]. Undergraduate students read more e-journal online if they believe it is useful for them to become successful EFL learners. This finding proves that one of the ways to promote the students online reading habit is to assign them reviewing and summarizing ELT research- articles from ejournals and make use the synopsis as references which later they can use to complete academic tasks, such as writing summaries, essays as final-report, research proposal, and research report.

Second, finding shows that students were not only able to write down the academic tasks completely, they also produced the summaries, essays as final-report, research proposal, and research report in English as well. This fact opposed to the previous research findings reported that students accustom to go online to read. Unfortunately, they go online for entertainment purposes more often than they do for educational purposes [2]; [3]; [8]. However, the finding supports the previous research that reports, students acknowledge the importance of reading habit and most of them (62\%) claim they read only for the purpose to pass the examination. This infers that students go online regularly not only for entertain themselves but it also challenges them to read English texts online via e-journals due to the reason they believe if they read more online they have many more references that support their argument whenever they write summaries, essays as finalreport, research proposal, and research report in English to complete their study. So that they can pass all subjects as earlier as possible. This spirit leads them to do more and more reading online e-journals.

Third, findings reveal, undergraduate students, read and refer more to the following e-journals: TEFLIN, RELC, The Asian EFL Journal, and The Journal of Asia TEFL. Students know well more e-journals where they can find ELT-researchbased articles as references which were relevant to the topics they are going to write later. So that the synopsis they draw are very useful to support their arguments if they wanted to write summaries, essays as final-report, research proposal, and research report. In addition, those e-journals are all online and higher index journals among others in Asia countries. These ejournals are well known as national and international accredited-journals. This finding supports the previous research findings reported that $70 \%$ the majority students, take notes on paper when reading from a screen and $28 \%$ use a word processor to record notes. This indicates, students in a developing country like, Ireland students have good reading habit online. This indicates that one of the characteristics of 
developing countries is that the young people, particularly students at the university have good reading habit online. They go online every day not only reading for having fun but also do it regularly for academic purposes.

And last, the findings revealed that all students perceived that reviewing and summarizing ELT-research based articles from e-journals to complete academic tasks promoting online reading habit among undergraduate students. This fact counter the previous finding explained that the EFL students are the reluctant and lack of interest in reading, for some reasons and factors. For example, it is due to the limited background knowledge, inability to understand the context, and complicated organization of the text $[13,14,15]$. They reluctant to read online, because online texts integrate a range of symbols, audio, interactive tables, virtual reality environments and many more in English [6]; [19]; [20], for example, in Turkey students rarely read journal articles online they prefer to read online news, emails, weather reports and comic strips [5].A research conducted in Taiwan, reveals that the students have fairly satisfactory English proficiency, however, in general, they are not interested in after-class English reading [8]. A research conducted in Malaysia reports, students accustomed to going online to read. Unfortunately, they go online for entertainment purposes more often than they do for educational purposes [2]. These indicate that many developing countries in Asia still encounter the same problem that is how to develop online reading habit among young people in each country. The current finding reveals that in Indonesia, undergraduate students perceive that reviewing and summarizing ELT-research based articles from e-journals to complete academic tasks promoting online reading habit among undergraduate students. They do not only acknowledge that reading habit is essential to complete their study, but they also claimed reading online is the worth effort to let them know more national and international accredited e-journals among Asia countries. They reviewed and summarized ELT research based-articles from those higher indexed e-journals to complete their academic tasks. As a result, as EFL students they confidently write down summaries, essays, research proposal and research report in English because they have read and reviewed, and referred based on well-known national and international accredited e-journals in Asia.

All in all, it is suggested that the availability of accessible E-Library across universities all over Indonesia is urgent to provide in order promoting online reading habit and developing quantity and quality of research among faculty members. Also, a research focuses on the use of e-journals to develop online reading habit among EFL teachers in Indonesia is necessary to conduct in the future.

\section{REFERENCES}

[1] Abidin, M. J. Z. A Survey of Online Reading Habits of Rural Secondary School Students in Malaysia. International Journal of Linguistics, Vol.3, No. 1, pp. 1-18,2011.
[2] Abidin, Z bin M, J, Pourmohammadi, M, Varasingam, N, and Lean, O.C.The Online Reading Habits of Malaysian Students. The Reading Matrix, Vol.14 No.2, pp. 164-172, September 2014.

[3] Acheaw, M.O \& Larson, A.G. Reading habit among Students and it Effect on Academic Performance: A Study of Students of Koforidua Polytechnic. Library Philosophy and Practice 6-5, pp 1-22, 2014.

[4] Adetunji, A. Factor Affecting Reading Habit of Secondary Schoo Students in Osogho Metropolis, Social Science 2 (1), pp.102-105, 2007.

[5] Akarsu, O \& Dariyemez, T. The Reading Habit of University Students Studying English Language and Literature in The Digital Age. Journal of Language and Linguistics Studies, 10 (2), pp. 85 - 99, 2014.

[6] Ali, A. ZM; Wahid, R Samsudin, K \& Idris, M.Z. Reading on The Computer Screen: Does Font Type has Effects on Web Text Readability? International Education Studies, Vol 6, No.3, pp. 26 - 35, 2013.

[7] Cahyani, $\mathrm{H}$ and Cahyono, B.Y. Teacher Attitude and Technology Use in Indonesia in EFL Classroom. TEFLIN Journal, Vo.23, No.2, pp. 130148, July 2012.

[8] Chiang, I.CN. Reading Habit, Language Learning Achievement, and Principles of Deep Knowledge. Linguistics and Literature Studies 4(3), pp. 203-212, 2016.

[9] Dudeney, G\& Hockly, N. ICT in ELT: how did we get here and where are we going? ELT Journal vol. 66/4, pp. 533-542, October. 2012)

[10] Falc, E.O. An Assessment of College Students' Attitude towards Using an Online E-textbook. Interdisciplinary Journal of E-Learning and Learning Objects, Vol 9, pp. 1-12, 2013.

[11] Floris, F. Debora. 2014. Using Information and Communication Technology (ICT) to Enhance Language Teaching and Learning. TEFLIN Journal, Vol 25, No 2, July. 2014

[12] Huang, S; Matthew, C; Blackblock, J \& Garza, M. Reading Habits of College Students in The United States. Reading Psychology, 35, pp. 437-467, 2014.

[13] Iftanti, E. A Survey of the English Reading Habits of EFL Students in Indonesia. TEFLIN Journal, Vol 23, No 2, pp. 149-164, July 2012.

[14] Iftanti, E. What Makes EFL Students Establish Good Reading Habits in English. International Journal of Education and Research. Vol.3 No.5, pp. 365-374, May 2015

[15] Jusosh, Z and Abdullah, L. Online Survey of Reading Strategies (OSORS): Students' Online Reading in Academic Context. Malaysian Journal of Distance Education 17 (2), pp. 67-81 (2015).

[16] Karim, N.S \& Hasan, A. Reading Habits and Attitude in The Digital Age: Analysis of Gender and Academic Program Differences in Malaysia. The Electronic Library, Vo.25 (3), pp. 285-298, 2007.

[17] Oktamelinae, I. The Effect of The Directed Reading-Thinking Activity (DR-TA) Strategy on The Reading Comprehension Ability of SMAs' Students. Unpublished Thesis. State University of Malang, November 2013.

[18] Mlay, S.V, Sabi, H, Tsuma, C, Langmia, K, Mbarika, V.A, and Kituyi Uncovering Reading Habit of University Students in Uganda: Does ICT Matter? International Journal of Education and Development Using Information and Communication Technology (IJEDICT), Vol. 11, Issue 2, pp. 38-50, 2015.

[19] Ogesyik, M.C \& Akayay, E. Investigating Reading Habits and Preferences of Students Teachers at Foreign Language Department. The International Journal of Language Society and Culture Issue 28, pp. 7279, 2009.

[20] Renandya, W.A. The Power of Extensive Reading. RELC Journal, 38(2), pp. 133-149, 2007.

[21] Vandenhoek, T. Screen Reading Habit among University Students. International Journal of Education and Development Using Information and Communication Technology Vol 9, Issue 2, pp. 37-47, 2013. 